\title{
AUTORIZAÇÃO EPISTÊMICA E ACIDENTALIDADE
}

\author{
Roberto Hofmeister Pich*
}

SÍNTESE - Esta é uma análise de um item do "externalismo de função própria" de Alvin Plantinga. A seguir, exponho o argumento de Peter Klein, contra o conceito de autorização [warrant] de Plantinga, no qual é mostrado por que ela não contém condições suficientes para o conhecimento, bem como as reações de Plantinga, nas quais se verifica um aprimoramento da mesma teoria. Sugiro uma avaliação teórica dos conteúdos propostos e exponho revisitas à condição do ambiente cognitivo, enfocada no debate. Proponho, ao final, uma resolução do problema, restrita aos termos da teoria de autorização por função própria.

PALAVRAS-CHAVE - Autorização epistêmica. Acidentalidade. Problemas de Gettier. Externalismo. Função própria. Ambiente cognitivo.
ABSTRACT -This is an analysis of an aspect of Alvin Plantinga's "proper function externalism". I expound Peter Klein's argument against Plantinga's concept of warrant, where it is shown why it doesn't contain sufficient conditions for knowledge, as well as Plantinga's reactions, where an improvement of the same theory is put forward. I propose a theoretical evaluation of the views in question and discuss recent analyses of the condition of cognitive environment, which is one of the focal points of the debate. Finally, I propose a resolution to the problem within the confines of the proper function theory of warrant. KEY WORDS - Epistemic warrant. Accidentality. Gettier problems. Externalism. Proper function. Cognitive environment.

\section{Introdução}

Este é um ensaio crítico sobre um elemento importante do "externalismo de função própria" de Alvin Plantinga. Foi assumido por ele, e notado pelos interlocutores, que é defendida na sua trilogia sobre epistemologia ${ }^{1}$ uma concepção de externalismo em franca distinção ao internalismo, tomando-se que, para este, e de modo algum para aquele, só aquilo ao que o sujeito tem grau elevado de acesso cognitivo interno pode contribuir ao estatuto epistêmico de crenças. ${ }^{2}$ Foi de início tentador pensar que o externalismo de função própria seria próximo à conhecida forma de externalismo chamada "confiabilismo" - em especial na terceira condi-

* Programa de Pós-Graduação em Filosofia da PUCRS.

Cf., nas Referências bibliográficas, Alvin PLANTINGA 1993a, 1993b e 2000.

Cf. Alvin PLANTINGA, Warrant: the current debate, p. 5-6, 183-4.

\begin{tabular}{|l|l|l|l|l|l|}
\hline VERITAS & Porto Alegre & v. 50 & n. 4 & Dezembro 2005 & p. 249-276 \\
\hline
\end{tabular}


ção de warrant por função própria -, chegando a ser chamado por Alston de "confiabilismo plus", por não ser completamente diferente do confiabilismo, mas por trazer exigências extras. ${ }^{3}$ Justamente os "extras", satisfeitos, em especial as condições primeira e segunda, segundo Plantinga (cf. abaixo), remediam discrepâncias visíveis, em situações possíveis, em que se pode alcançar confiabilidade sem warrant. $^{4}$

Antes de precisar a "função própria", vê-se que é warrant ou "autorização" (ou "autorização epistêmica", para isolar o seu uso em teoria do conhecimento) o conceito epistemológico que, para Plantinga, é essencial ao conhecimento. "Autorização" é o que deve ser acrescido à "crença verdadeira", tornando-a "conhecimento". Não é "justificação" que se adiciona à crença verdadeira, mas "autorização", e "conhecimento" é crença verdadeira autorizada. "Justificação" deve ser recusada como a "quantidade" faltante à crença verdadeira, para gerar conhecimento, essencialmente porque não está livre dos contra-exemplos de Gettier, que, como é sabido, mostrou, num artículo histórico, que crença verdadeira mais justificação não constituem conhecimento. ${ }^{7}$ Os exemplos de Gettier mostram que há casos em que uma crença $p$ está justificada para $S$, na medida em que $S$ tem evidência para $p$; ora, é possível que essa crença justificada seja falsa e, como tal, seja base adequada a uma crença verdadeira q: esta, então, seria justificada, mas não conhecimento. "Autorização", seja qual for o seu conteúdo, é o conceito que deve bastar para excluir da análise do conhecimento "acaso", "sorte", numa palavra, "acidentalidade". Como pontuou Klein, uma crença tem autorização se é verdadeira e não é obtida por acidente, "do ponto de vista cognitivo". "Internalismos", subtipos de deontologismo, supondo-se os casos de Gettier stricto ou lato sensu, não têm tal imunidade. ${ }^{8}$ Uma teoria de autorização apresenta "aquela propriedade de uma crença verdadeira em virtude da qual ela não é acidentalmente verdadeira" do ponto de vista cognitivo, medindo-se, assim, como teoria do conhecimento. ${ }^{9}$

3 Cf. William ALSTON, Epistemic warrant as proper function, in: Philosophy and Phenomenological Research, p. 398.

4 W. Alston, cf. ibidem, p. 401-2, como outros autores, mostra que, em verdade, reliability, e não proper function, é suficiente e necessária para warrant, em que, sob certos aspectos, confiabilidade e função própria se repugnam e separam.

5 Cf. A. PLANTINGA, Warrant: the current debate, p. 3-5; idem, Warrant and proper function, p. v-vi (Preface).

6 Há críticas ao modo como Plantinga define warrant e graus de warrant, por não escapar de confusões entre "autorização" e "justificação". A definição de warrant em termos de verdade, crença e conhecimento acarretaria a inconsistência de aspectos da "definição funcional" de Plantinga. Joel PUST, Warrant and analysis, in: Analysis, p. 51-7, afirma que a (terceira) definição de warrant como "aquele $X$ (que poderia vir em graus), tal que $S$ sabe que $p$ sse (i) $p$ é verdadeira, (ii) $S$ crê que $p$ e (iii) a crença de $S$ que $p$ tem $X$ (ou $X$ o suficiente)" é, em princípio, imune a objeções. Porém, ela deixa em aberto se warrant vem em graus, e uma resposta plena a isso suporia uma análise completa do conhecimento.

Cf. Edmund GETTIER, Is justified true belief knowledge?, in: Analysis, p. 121-3.

8 Cf. A. PLANTINGA, Warrant: the current debate, p. 3-161.

9 Cf. Peter KLEIN, Warrant, proper function, reliabilism, and defeasibility, in: Jonathan L. KVANVIG (ed.), Warrant in contemporary epistemology, p. 98. 
Desconsidero, no presente ensaio, a miríade de críticas à autorização segundo Plantinga, desde as obras centrais, ${ }^{10}$ a qual sugeriria separar autorização como (i) aquilo que, acrescido à crença verdadeira, produz conhecimento (autorização-c) e autorização (ii) segundo as condições de Plantinga (autorização-p). ${ }^{11}$ Por ora, quero identificar as diretrizes da teoria de Plantinga, resumidas em vários lugares. ${ }^{12}$ O conteúdo básico da autorização de uma crença é ser produzida por uma faculdade cognitiva funcionando de modo próprio, fazendo o que foi designada a fazer. Uma "função própria" cognitiva exercida é um paradigma de autorização e de conhecimento. " "Função própria", ademais, liga-se diretamente a um "plano de desígnio" do órgão ou mecanismo em uso - no modo suposto como "o devido" a ele, como opera quando opera "propriamente", com ausência de disfunção, ou, ainda, de acordo com a função ou o propósito último (e, pois, específico) ao qual foi "construído". ${ }^{14}$ As noções centrais "função própria" e "plano de desígnio" são interdefiníveis. ${ }^{15}$ Plantinga as desdobra, ao apresentar as seguintes condições necessárias e suficientes: uma crença $B$ tem autorização sse (1) "as faculdades cognitivas envolvidas na produção de $B$ estão funcionando propriamente" (incluindo "sistemas de anuladores relevantes, bem como aqueles sistemas (...) que oferecem inputs proposicionais ao sistema em questão"); (2) o ambiente cognitivo do sujeito é suficientemente semelhante àquele ao qual as

10 Quase cada elemento relevante da teoria básica de Plantinga sobre as condições da autorização foi criticado. Crítica típica é a de que elas não esclarecem, mas ofuscam o conceito de conhecimento, por causa de explanação incoerente do conceito de "função própria", dada a falsa suposição de haver sentido comum para o naturalista e para o supranaturalista; cf., por exemplo, Richard SWINBURNE, Response to Warrant, in: Philosophy and Phenomenological Research, p. 415s. Insuficiente seria a definição de "função própria" também por não se distinguir com clareza entre o funcionamento e o uso das faculdades de um sujeito (na verdade, o que significa uma "faculdade" como "processo cognitivo" ou "habilidade intelectual" não é item bem explicado por Plantinga); cf. Matthias STEUP, Proper and improper use of cognitive faculties: a counterexample to Plantinga's proper functioning theory, in: Philosophy and Phenomenological Research, p. 409-13. Típica também é, desde antes da publicação mesma da obra epistemológica de Plantinga, a crítica à teoria de autorização por função própria enquanto analisada em termos de processo ou agente de desígnio, em que se concluiria que a teoria de Plantinga ou é sujeita a contra-exemplos fortes ou não é nem satisfatória nem alternativa, comparada ao confiabilismo; cf. James E. TAYLOR, Plantinga's proper functioning analysis of epistemic warrant, in: Philosophical Studies, p. 185-202. Não menos característica é, enfim, a forma de crítica severa de que a teoria de autorização de Plantinga falha porque a adição da "exigência de funcionamento próprio" das faculdades cognitivas à teoria de autorização além de uma "exigência de confiabilidade" - é um engano; cf. Richard FELDMAN, Proper functionalism, in: Nous, p. 40-9.

11 Cf. Richard GREENE and N. A. BALMERT, Two notions of warrant and Plantinga's solution to the Gettier problem, in: Analysis, p. 132-3.

12 Cf. também Alvin PLANTINGA, Précis of Warrant: the current debate and Warrant and proper function, in: Philosophy and Phenomenological Research, p. 393-6; idem, Warrant and accidentally true belief, in: Analysis, p. 140s.

13 Cf. A. PLANTINGA, Warrant and proper function, p. 4-11.

14 Ibidem, p. 11-7.

15 Cf. A. PLANTINGA, Précis of Warrant: the current debate and Warrant and proper function, op. cit., p. 395. Essa interdefinibilidade sofre de enormes dificuldades e sérias conseqüências, tanto se aceita quanto se negada; cf., por exemplo, James E. TAYLOR, Plantinga on epistemic warrant, in: Philosophy and Phenomenological Research, p. 421-6. 
suas faculdades cognitivas são designadas; ${ }^{16}$ (3) o segmento cognitivo ou módulo especificado por um "triplo" do plano de desígnio (circunstância, resposta doxástica ou crença de faculdade(s) específica(s) e propósito) "governando a produção da crença em questão envolve", como função, "a produção de crenças verdadeiras" (valendo o mesmo para "os elementos do plano de desígnio que governam a produção de crenças de input para o sistema em questão"); (4) "o plano de desígnio é bom", isto é, "há uma alta probabilidade estatística ou objetiva de que uma crença produzida de acordo com o segmento relevante do plano de desígnio, naquele tipo de ambiente, seja verdadeira". ${ }^{18}$ Adiciona-se ainda que o "grau de autorização", vinculando-se "grau" aos diversos modos próprios de funcionamento de faculdades (perfeito, muito bom, aproximado, etc.) e ao bastante de similaridade ambiental com as circunstâncias às quais os poderes epistêmicos foram em si designados, é dado por uma função crescente da firmeza da crença de $S$ que $B$. Por isso, nota-se que a autorização vem em graus: uma crença $B$ constitui conhecimento para $S$ só se tem um grau suficiente da "quantidade" em apreço. ${ }^{19}$ É imprudente discutir, aqui, a grandeza teórica desse esquema.

Uma das críticas mais conseqüentes à teoria de Plantinga partiu de um artigo de Peter Klein..$^{20}$ A crítica é, em si, multifacetada. Klein argumenta que "função própria" não é nem uma condição suficiente nem uma condição necessária ao conceito de "autorização". Mostra que há crenças que resultam de faculdades cognitivas funcionando propriamente, mas que, não obstante, são verdadeiras acidentalmente, do ponto de vista cognitivo. Ademais, há crenças que não são produzidas pelo suposto "funcionamento próprio" de faculdades cognitivas e são verdadeiras não-acidentalmente, do ponto de vista cognitivo. ${ }^{21}$ Pretendo, no que segue, (1) refazer apenas o argumento de Klein, contra a versão de autorização de Plantinga, no qual é mostrado por que ela não contém condições suficientes para o conhecimento, (2) bem como a reação de Plantinga, onde se verifica um genuíno aperfeiçoamento da mesma teoria. Depois, (3) sugiro uma avaliação teórica dos conteúdos propostos e exponho revisitas à cláusula de ambiente cognitivo, problematizada no debate, propondo (4 e conclusão) uma resolução, supostamente superior às demais, àquela condição, restrita aos termos da teoria de autorização por função própria de Plantinga.

\footnotetext{
Cf. A. PLANTINGA, Warrant and proper function, p. 7-8.

Ibidem, p. 22s.

Ibidem, p. 194 (também p. 26-31).

Ibidem, 8-11, 194; idem, Warrant and accidentally true belief, op. cit., p. 140

Cf. P. KLEIN, Warrant, proper function, reliabilism, and defeasibility, in: J. L. KVANVIG (ed.), op. cit., p. 97-130.
}

Ibidem, p. 99-100. 


\section{A ameaça da acidentalidade}

Klein foi bem-sucedido em mostrar o quão diferentes são as versões do externalismo de confiabilidade e do de função própria, quanto à ameaça da acidentalidade da crença verdadeira. Formulo com remendos o exemplo originalmente forÇOSO: $:^{22}$

O Sr. Lesão tinha um aparato cognitivo perfeito até que, num desafortunado dia, sofreu uma lesão cerebral séria. Desde então, ele não mais consegue pôr as coisas em ordem, e a maior parte do seu conhecimento desaparece. A sua lesão cerebral lhe causa todos os tipos de percepções anormais e faz com que realize inferências deveras peculiares. Mas, além de causar no Sr. Lesão todos os tipos de proposições falsas, a sua lesão cerebral faz com que ele creia que tem uma lesão cerebral. Nota-se, ademais, que o Sr. Lesão não tem evidência - pelos sentidos, pela memória, introspecção, etc. - de que é anormal dessa maneira: interpreta o seu grupo de crenças incomuns como resultado de concepções originais e ousadas que refletiu sobre o mundo e a existência. Assim, a sua forma particular de lesão cerebral e as leis da natureza são tais que a sua lesão cerebral causa nele a crença em ao menos uma proposição verdadeira, junto com muitas outras crenças falsas.

Mesmo pressupondo que formulações confiabilistas do conhecimento responderiam ao contra-exemplo com muito mais sofisticação, ${ }^{23}$ parece-me justo afirmar que, (i) para o confiabilista, uma crença verdadeira é acidental do ponto de vista cognitivo sse é verdadeira, mas o processo que a produziu é tipicamente um que não resulta em crenças verdadeiras. Assim, o Sr. Lesão tem conhecimento, porque a crença verdadeira, do ponto de vista cognitivo, não é acidentalmente verdadeira. (ii) Para o adepto do externalismo de função própria, a acidentalidade cognitiva, ali, não se dá por "falta de evidência", mas porque a crença surge como resultado de uma "anormalidade cognitiva". A receita de contra-exemplos é pensar num evento e, tal que ele causa que $S$ creia que e ocorre, onde e causa que $S$ forme a crença em questão em virtude de uma anormalidade cognitiva. ${ }^{24}$ É um acidente, do ponto de vista cognitivo, que a crença seja verdadeira, pois há falha na obtenção da crença, conforme o plano de desígnio da estrutura noética. O exemplo força a adição de as faculdades noéticas de $S$ envolvidas na produção daquela

${ }^{22}$ Ibidem, p. 100-1. O exemplo, cf. ibidem, p. 124, nota 10, se remete originalmente a Ernest Sosa e A. PLANTINGA, Warrant: the current debate, p. 195, no último caso em crítica à definição de conhecimento associada a Fred Dretske: "D5 $K$ sabe que $s$ é $F$ sse $K$ crê que $s$ é $F$ e há um estado de coisas o ser $G$ de $r$ tal que (1) o ser $G$ de $r$ causa a crença de $K$ de que $s$ é $F$ e (2) $\mathrm{P}((s$ é $F) /(o$ ser $G$ de $r \wedge k))=1$ e $\mathrm{P}((s$ é $F) / k<1$ ”. A. Plantinga, cf. ibidem, p. 195-7, traz três exemplos.

23 De qualquer modo, P. KLEIN, Warrant, proper function, reliabilism, and defeasibility, in: J. L. KVANVIG (ed.), op. cit., p. 124, nota 12, menciona a concordância de Dretske com o exemplo, se ficar claro que (1) o Sr. Lesão possuía a informação de que sofria de certa lesão cerebral e que (2) a origem da obtenção dessa informação é a lesão cerebral específica. A versão externalistaconfiabilista de Dretske está calcada, como se sabe, no conceito de "informação".

24 Para a teoria de autorização por função própria, a propósito, o confiabilismo em geral estaria entre a Scylla da aplicabilidade de tal fórmula de contra-exemplos e a Charybdis do conhecido "problema da generalidade" para o confiabilismo; cf. Alvin PLANTINGA, Reliabilism, analyses and defeaters, in: Philosophy and Phenomenological Research, p. 431-4; idem, Why we need proper function, in: Nous, p. 73-5. 
crença funcionarem propriamente. ${ }^{25}$ A crença do Sr. Lesão só é conhecimento se gerada pelo aparato cognitivo funcionando de modo próprio. Do contrário, é, ou ao menos pode sempre ser, um acidente cognitivo. $O$ adepto da autorização por função própria diz, pois, que o Sr. Lesão não tem conhecimento, porque a crença verdadeira é acidentalmente verdadeira, cognitivamente. Numa terceira argumentação, (iii) o defensor da teoria de anulabilidade admite que uma crença é acidentalmente verdadeira se há evidência genuína que anula a evidência na qual se apóia, mas que permanece oculta ao sujeito. Também aqui o sujeito teria "sorte" de chegar à crença verdadeira. ${ }^{26}$ Teorias de anulabilidade não serão tratadas neste estudo. $^{27}$

O importante é que Klein mostrou que, mesmo se uma crença verdadeira for produzida sob as condições 1-4, ela pode ser acidentalmente verdadeira do ponto de vista cognitivo: logo, uma crença verdadeira não precisa ser produzida por faculdades funcionando propriamente, para que seja conhecimento. A justa lição tirada por Plantinga dos problemas de Gettier fora que, no sentido internalista, é possível falhar em se ter conhecimento, porque algo, não acessível ao sujeito, como as faculdades cognitivas sob disfunção, ou o ambiente cognitivo "poluído" assimétrico aos módulos cognitivos aplicados ao conhecimento, se impõe, podendo influir na obtenção de crença verdadeira. Porém, é decisivo notar que o aparato cognitivo pode estar funcionando de modo perfeito, nas condições de Plantinga, e ser meramente acidental, cognitivamente, ter alcançado a crença verdadeira. Tome-se o exemplo adaptado, a partir de Klein, da Sra. Jones, a Sortuda: ${ }^{28}$

A Sra. Jones crê que possui um Ford funcionando bem. Ela forma essa crença em circunstâncias normais, usando o seu aparato cognitivo, que funciona de modo perfeito. Mas, como às vezes acontece, sem o conhecimento da Sra. Jones, o seu Ford é atingido e virtualmente demolido pelo caminhão do lixo - enquanto ele está parado lá fora, no estacionamento da sua repartição. Porém, também sem o conhecimento da Sra. Jones, ela recém ganhou um Ford, em perfeito funcionamento, no Concurso Ford, que corre uma vez por ano, nessa época, na companhia onde ela trabalha.

Neste contra-exemplo ${ }^{29}$ - aceitando que um contra-exemplo mostra algo só se é claramente possível, e não é claramente possível se mantém dúvida sobre a sua

25 Cf. A. PLANTINGA, Warrant: the current debate, p. 197.

${ }^{26}$ Cf. P. KLEIN, Warrant, proper function, reliabilism, and defeasibility, in: J. L. KVANVIG (ed.), op. cit., p. 102-3.

${ }^{27}$ P. Klein, na verdade, cf. ibidem, p. 99-100, 103, 112-22, defende que uma acepção superior de autorização é oferecida na sua teoria de anulabilidade. Algo semelhante propõe Marshall SWAIN, Warrant versus indefeasible justification, in: Jonathan L. KVANVIG (ed.), Warrant in contemporary epistemology, p. 131-46.

28 Cf. P. KLEIN, Warrant, proper function, reliabilism, and defeasibility, in: J. L. KVANVIG (ed.), op. cit., p. 104-5.

${ }^{29}$ Diversos outros exemplos têm sido utilizados na literatura, e admitidos por Plantinga, como cumprindo o mesmo propósito de delinear a acidentalidade remanescente, após a apresentação original das condições de autorização por função própria: o caso do relógio parado de Bertrand Russell, o caso das fazendas de fachada de Carl Ginet, o caso dos gêmeos idênticos Paulo e Pedro, etc. Cf. Thad M. BOTHAM, Plantinga and favorable mini-environments, in: Synthese, p. 431-2. 
possibilidade ${ }^{30}$-, todas as condições de autorização por função própria são obtidas. Mas, a crença verdadeira não é um caso de conhecimento, porque é claramente obtida por acidente, cognitivamente. E a lição básica é que há, a partir disso, "um Problema de Gettier Generalizado", isto é, "se autorização pode ser transferida a partir de uma crença falsa, autorizada [como "O meu Ford, que estacionei há alguns minutos, encontra-se lá fora"], através do exercício próprio das nossas faculdades para uma crença verdadeira [como "Eu (Sra. Jones) possuo um Ford em bom funcionamento"], então aquela crença verdadeira será autorizada, mas não será conhecimento". ${ }^{31}$ O que fazer, a partir daí, com a teoria original?

\section{Reparos à condição do ambiente epistêmico}

O ponto por ora mais decisivo da confissão de mea culpa de Plantinga foi o reconhecimento de que o seu tratamento dos problemas de Gettier, ou quaseGettier, é defeituoso. ${ }^{32}$ Há outros exemplos, além do da Sra. Jones, mas basta lembrar que, em todos, autorização segundo função própria acaba por permitir obtenção de crença verdadeira e justificada, mas que não constitui conhecimento. Aprende-se, com os novos e antigos problemas, sobre a estrutura do conhecimento: neles, a crença verdadeira não constitui conhecimento, porque é só acidentalmente que $S$ forma uma crença verdadeira da situação.

De certa forma, porém, a localização da insuficiência de condições para o conhecimento tem o mesmo endereço: ao relevar a condição ambiental, Plantinga só conseguira tratar de alguns casos de Gettier, aqueles originais que envolviam uma "poluição ambiental cognitiva", nos quais o ambiente cognitivo se desvia do paradigma ambiental ao qual as faculdades estão designadas. Envolviam erros relativamente menores de adequação entre capacidade cognitiva e ambiente, incorrendo na acidentalidade cognitiva da crença verdadeira. ${ }^{33}$ Não creio que Plantinga entenda (ou possa entender) os casos típicos-originais de Gettier exatamente no mesmo plano do caso de Klein. Os primeiros continham erro entre um dado segmento do plano de desígnio cognitivo e um dado ambiente. É correto dizer, com Greene e Balmert, que todos os casos de Gettier em geral incluem um tipo de "glitch na situação cognitiva", ou no funcionamento das faculdades cognitivas do que forma a crença, ou no ambiente cognitivo. ${ }^{34}$ Julgo acertado afirmar, ademais,

30 A lembrança é recorrente, pois somente nos termos de razões não-controversas, num contraexemplo, algo é realmente mostrado como equivocado e carente de correção; cf. Alvin PLANTINGA, Warrant and designing agents: a reply to James Taylor, in: Philosophical Studies, p. 207-8; J. E. TAYLOR, Plantinga on epistemic warrant, op. cit., p. 422-3.

31 Cf. P. KLEIN, Warrant, proper function, reliabilism, and defeasibility, in: J. L. KVANVIG (ed.), op. cit., p. 105-8.

32 Reconheceu, além disso, não ter considerado as "teorias de anulabilidade" no que tange aos problemas de Gettier, nos dois volumes iniciais da sua trilogia; cf. Alvin PLANTINGA, Alvin Plantinga replies, in: Jonathan L. KVANVIG (ed.), Warrant in contemporary epistemology, p. 308s. Sobre a sua insatisfação com as mesmas, cf. ibidem, p. 317-26.

33 Ibidem, p. 310; idem, Warrant and proper function, p. 31-7.

34 Cf. GREENE and BALMERT, Two notions of warrant and Plantinga's solution to the Gettier problem, op. cit., p. 134 
que casos de Gettier em específico ou originais apresentam "poluição cognitiva" entre as cláusulas (2) e (3), ${ }^{35}$ mas não necessariamente só na cláusula (2). Casos de Gettier em geral apresentam problemas na cláusula (1), ou na cláusula (2), ou entre as cláusulas (2) e (3), ou entre as cláusulas (1), (2) e (3). ${ }^{36}$ Casos de GettierKlein, que podem ser tomados como casos gerais, explicitam dificuldades particulares com a cláusula (2).

Ainda nesse tocante, há quem entenda que a estratégia de Plantinga para superar problemas de Gettier e reconciliar autorização-p com autorização-c, não admitindo crenças autorizadas-p falsas - supostas crenças autorizadas-p falsas que teriam o grau de autorização suficiente para o conhecimento -, consiste em argumentar que a produção de uma crença falsa, satisfazendo as condições (3) e (4), (i) envolve ou uma disfunção no mecanismo cognitivo do sujeito, violando a condição (1), ou (ii) um ambiente que não é suficientemente similar àquele tipo ao qual as faculdades cognitivas foram designadas, violando a condição (2). ${ }^{37}$ Deixese de lado a primeira parte da estratégia. E, antes de mais nada, é clara a réplica de Plantinga de que segmentos do plano de desígnio cognitivo admitem, nas "negociações e concessões" - vide exemplos Müller-Lyer -, atitudes cognitivas "próprias" que servem só indiretamente ao conhecimento (à produção do conhecimento do verdadeiro, por execução de função própria direta). Pode-se realizar, no deserto escaldante, o exercício de crença na existência do oásis, avistado a algumas centenas de metros, e ocorrer que isso é verdadeiro, mas apenas por acidente, dado que wishful thinking não se volta diretamente à produção de crença verdadeira no ambiente que é adequado ao seu exercício. Essa crença verdadeira, suprida da autorização de tal mecanismo produtor de crenças, não é conhecimento: é cognitivamente acidental. Uma crença verdadeira tem autorização epistêmica somente se é produzida por um segmento do plano de desígnio diretamente voltado à verdade, pois, então, não é acidental. ${ }^{38}$ No mesmo caso, pode-se dizer que a crença na existência do oásis, se fosse falsa, teria certo grau de autorização - pois cumpre o propósito direto de servir à ação persistente e indiretamente à continui-

35 A meu juízo, sobre os casos (originais) de Gettier na disputa Plantinga-Feldman se releva a suficiência da resposta de Plantinga quanto ao adequado módulo, especificado por um triplo, que objetive, segundo o plano de desígnio do mecanismo em questão, a geração de crenças verdadeiras. Trata-se de "poluição" entre as cláusulas (2) e (3). Nesse tratamento dos casos de Gettier, o defeito teórico, para Feldman, está sobretudo na implausível especificidade e na inaceitável arbitrariedade com que módulos cognitivos são criados, para explicitar a ausência de conhecimento nos casos de Gettier e a imunidade a eles, segundo a autorização por função própria. Cf. Richard FELDMAN, Plantinga, Gettier, and warrant, in: Jonathan L. KVANVIG (ed.), Warrant in contemporary epistemology, p. 215-6.

36 A. PLANTINGA, Warrant and proper function, p. 32-7, oferece exemplos e caracterizações nesses termos. Cf. idem, Why we need proper function, op. cit., p. 69-70. Cf. também a análise breve de Robert K. SHOPE, Gettier problems, in: Edward CRAIG (ed.), Routledge Encyclopedia of Philosophy, Vol. 4, p. 57-8.

37 Cf. GREENE and BALMERT, Two notions of warrant and Plantinga's solution to the Gettier problem, op. cit., p. 136s.

38 Cf. A. PLANTINGA, Warrant and proper function, p. 38-40; idem, Alvin Plantinga replies, in: J. L. KVANVIG (ed.), op. cit., p. 310-2. 
dade do plano de conhecer a verdade - podendo ser parte de um compromise cognitivo superior. Mas, nesse segundo caso, a crença falsa não teria autorizaçãop para o conhecimento, possibilitando que crenças verdadeiras, dali deduzidas, fossem obtidas acidentalmente, num típico cenário de Gettier - nos moldes da teoria de autorização por função própria apresentada de início. A confusão presente deve ser eliminada com a lembrança de que autorização vem em graus. Aquela crença falsa não teria autorização no grau suficiente ao conhecimento. ${ }^{39}$

Convém mesmo seguir a segunda parte da estratégia. Afinal, com base no exemplo Gettier-Klein, constata-se que a crença é produzida do mesmo modo, aplicando-se as condições 1-4, na situação sem o cenário e na com o cenário de Gettier. Que a crença constitui conhecimento numa situação, mas não na outra, não é atribuível aos processos de produção de crença, tampouco pelo apelo à distinção "direta e indiretamente voltados à crença verdadeira". A mesma "quantidade" do aparato cognitivo, sob o governo da mesma "quantidade" do plano de desígnio, produz a mesma crença no mundo do Ford intacto e sem bilhete premiado e no mundo do Ford destruído e do número da sorte. Em ambos, dá-se o mesmo exercício das mesmas faculdades no mesmo "maxi-ambiente cognitivo". Mesmo aplicando as condições 1-4, a teoria de autorização de Plantinga falha. ${ }^{40}$ De outro modo: uma crença autorizada-p verdadeira só por acidente mostra que autorização-p não acarreta autorização-c e que a análise de autorização-c via autorização-p frustra. ${ }^{41}$ Ora, se há crença falsa autorizada-p e uma inferência dedutiva transfere autorização segundo autorização-p, pode haver crenças autorizadas-p verdadeiras acidentalmente, reobtendo-se a suscetibilidade ao problema de Gettier. Para todos os efeitos, Plantinga objetiva uma equivalência entre autorização-c e autorização-p, e naturalmente assume sobre aquela que, se uma inferência dedutiva é preservadora de autorização-c, não pode haver crença falsa autorizada-c, a qual estaria em contradição com a definição oferecida para autorização-c. ${ }^{42}$

${ }^{39}$ Cf. A. PLANTINGA, Warrant and accidentally true belief, op. cit., p. 141-2.

Cf. A. PLANTINGA, Alvin Plantinga replies, in: J. L. KVANVIG (ed.), op. cit., p. 312-3; Andrew CHIGNELL, Accidentally true belief and warrant, in: Synthese, p. 446.

41 Cf. GREENE and BALMERT, Two notions of warrant and Plantinga's solution to the Gettier problem, op. cit., p. 134.

42 Ibidem, p. 134-5. Trenton MERRICKS, Warrant entails truth, in: Philosophy and Phenomenological Research, p. 842s., tentou mostrar que o fato de autorização acarretar verdade não é tanto uma conclusão a ser tirada, na base de uma análise substantiva de autorização, mas mais uma condição de adequação para qualquer análise. A acepção de que autorização não acarreta verdade leva ou à contradição ou a um conjunto de idéias menos plausível do que a idéia de que a autorização de uma crença acarreta que ela é verdadeira. Dever-se-ia concluir que não é logicamente possível que uma crença autorizada seja falsa - ou: autorização acarreta verdade. Sharon RYAN, Does warrant entail truth?, in: Philosophy and Phenomenological Research, p. 184s., objetou que tal "conjunto de idéias menos plausível" não contém as únicas opções existentes, havendo uma abordagem factível de autorização, não abalada pelos elementos daquele conjunto. Trenton MERRICKS, More on warrant's entailing truth, in: Philosophy and Phenomenological Research, p. 627-8, aperfeiçoou o primeiro argumento, a partir de duas teses sobre autorização. (a) Se uma crença é autorizada ou não não é um fato bruto, mas tem superveniência sobre outros fatos. Se tenho uma crença autorizada $p$ num mundo, mas não no outro, o primeiro contém alguma diferença sobre a qual a diferença em 
Chamou-se essa indeterminação das condições 1-4 de "problema da resolução". ${ }^{43} \mathrm{Na}$ verdade, ele marca a indeterminação da condição (2), a do ambiente cognitivo ou do módulo do sujeito "funcionando num ambiente suficientemente similar ao tipo de ambiente para o qual as faculdades cognitivas de $S$ foram designadas". ${ }^{44}$ Assim, se uma crença tem autorização só se é formada num ambiente cognitivo apropriado, aquele ao qual a faculdade cognitiva foi designada por Deus ou pela evolução, tal ambiente é apenas um maxi-ambiente. Os poderes cognitivos são designados a funcionar nele, o ambiente do mundo de agora, ou noutro universo suficientemente semelhante para permitir a obtenção de conhecimento. O "nosso" maxi-ambiente cognitivo é geral, nele as faculdades produzem crenças verdadeiras, e ele "incluiria tais traços macroscópicos como a presença e as propriedades da luz e do ar, a presença de objetos visíveis, de outros objetos detectáveis por sistemas cognitivos do nosso tipo, de alguns objetos não-detectáveis desse modo, das regularidades da natureza, da existência e da natureza geral de outras pessoas", etc. ${ }^{45}$

Mas, também há um ambiente cognitivo menos global. Um maxi-ambiente pode conter "mini-ambientes": um em que um caminhão do lixo destrói o Ford, outro no qual ele passa de lado. Para toda crença $B$ e todo exercício $E$ de poderes cognitivos agindo em $B$, há um estado de coisas muito mais específico: um miniambiente cognitivo. Pode-se pensá-lo como um estado de coisas que inclui as circunstâncias epistêmicas relevantes como se dando, quando $B$ é formada. $O$ mini-ambiente cognitivo $M$ para $E$ agindo em $B$ (ou $M B E$ ) inclui o estado de coisas especificado por meu maxi-ambiente cognitivo, bem como traços mais específicos de minha situação epistêmica. Em qualquer exercício $E$ de faculdades cognitivas funcionando propriamente em $B$, conta-se com um evento produzindo uma crença verdadeira em alguns mini-ambientes, mas não em outros. Isso vale para o caso da Sra. Jones. O evento é, pois, relativo ao exercício particular dos poderes cognitivos em questão: no cenário indesejado, a Sra. Jones formaria a crença falsa de que o seu Ford repousa intacto no estacionamento; a crença não seria falsa se os elementos imprevistos que causam dano ao automóvel estivessem longe, também não seria formada se a Sra. Jones tivesse um detetive particular que monitorasse com câmeras o seu vistoso Ford vinte e quatro horas por dia. ${ }^{46}$ Daí que MBE é maximamente específico, "exceto para a verdade ou falsidade da proposição de que $S$ forma uma crença verdadeira por meio de $E$ "; um mini-ambiente cognitivo é "um estado de coisas diminuído com respeito àquela proposição". Ele é tão possível quanto a situação específica maximamente atual que inclui que $S$ forma uma crença verdadeira, se essa é formada por $S$, ou que $S$ não forma uma crença ver-

autorização sobrevém. (b) Então, aquela outra diferença deve envolver algum aperfeiçoamento na "situação epistêmica como um todo", com respeito à minha crença que $p$.

43 Cf. A. PLANTINGA, Alvin Plantinga replies, in: J. L. KVANVIG (ed.), op. cit., p. 313s.

44 Cf. GREENE and BALMERT, Two notions of warrant and Plantinga's solution to the Gettier problem, op. cit., p. 133.

45 Cf. A. PLANTINGA, Warrant and accidentally true belief, op. cit., p. 143.

46 Ibidem. Cf. idem, Alvin Plantinga replies, in: J. L. KVANVIG (ed.), op. cit., p. 314-5. 
dadeira, se de fato $S$ forma uma crença falsa, "dado que $M B E$ não inclui nem a proposição de que $S$ forma crença verdadeira, nem o seu oposto". ${ }^{47}$ Por isso, devese perguntar, agora, se um exercício $E$ de poderes cognitivos em $M$ conta ou não como gerador de crença verdadeira. ${ }^{48}$

Já se compreende, portanto, que um dado exercício $E$ de poderes cognitivos, que estão funcionando propriamente no maxi-ambiente ao qual foram designados, pode contar como produzindo crença verdadeira com respeito a um mini-ambiente cognitivo, mas não com respeito a outro. Certos mini-ambientes são favoráveis a um exercício de poderes cognitivos, outros são equivocados ao mesmo, embora as faculdades operem propriamente - e estejam em conformidade funcional com o maxi-ambiente. Pode-se funcionar com proper function no maxi-ambiente, mas sem proper function no mini-ambiente, pode-se obter crença verdadeira a partir de crença falsa, preenchendo as condições 1-4 originais, no maxi-ambiente, mas sendo aquela acidental, do ponto de vista cognitivo, e, assim, falso exemplo de conhecimento. ${ }^{49}$ Maxi- e mini-ambiente cognitivo devem ser favoráveis. ${ }^{50}$ A lição geral de tais casos de Gettier é que não basta à autorização epistêmica que o maxi-ambiente seja aquele ao qual as faculdades são designadas a produzir crença verdadeira: teorias de justification ou de warrant terão de superar a área de "resolução insuficiente". 51

Não obstante a suficiência dos contra-exemplos, Plantinga foi taxativo em dizer que a solução do problema da resolução e do problema de Gettier é deveras simples. ${ }^{52}$ É preciso ampliar a condição (2) com a "favorabilidade" (favorability) do mini-ambiente cognitivo. Autorização inclui uma condição ambiental, e essa deve ser entendida tal que especifique um mini-ambiente cognitivo favorável - também

47 Para as últimas citações, cf. ibidem, p. 315.

O argumento de Thomas M. CRISP, Gettier and Plantinga's revised account of warrant, in: Analysis, p. 44-5, de que o exposto não explana um mini-ambiente, pois há dúvida se um estado de coisas satisfaz tal definição, embora instigante, parece-me mal-formulado. Confunde-se " $M B E$ maximamente específico" simpliciter com "MBE maximamente específico" atual. A definição de MBE maximamente específico simpliciter dada por Plantinga é boa, levando em conta que ainda não inclui a "condição de favorabilidade", pois essa é dada justamente segundo a crença que é obtida (cf. abaixo, no texto principal). Antes da obtenção da crença, um MBE maximamente específico simpliciter pode ser favorável ou não. A confusão inicial de Crisp leva a outras, como à definição (a ser satisfeita e, nesses termos, portanto, desde o princípio do argumento) equivocada de $M B E-=$ df. (i) A (estado de coisas) está propriamente incluído em $C$ (circunstâncias epistêmicas maximamente especificadas), e (ii) $A$ é tão possível quanto $C$, dado que $A$ não acarreta nem a proposição de que $E$ (exercício de poderes cognitivos) produz crença verdadeira nem a sua negação - e à má avaliação do que seriam os estados de coisas ou MBES "mais próximos" de um certo $M B E$ maximamente específico, em que, dado um exercício lógico, resultariam problemas com a idéia de haver um ou $O$ estado de coisas mais próximo de tal $M B E$. Ora, o $M B E$ maximamente específico atual, que, pela definição, inclui que $S$ forma uma crença verdadeira, se $S$ forma essa, ou que $S$ forma uma crença falsa, se $S$ forma essa, tem obviamente como $M B E$ mais próximo justamente aquele que não inclui nem exclui a verdade ou a falsidade de que $S$ forma aquela crença verdadeira (ou falsa) ou a sua negação.

49 Cf. A. PLANTINGA, Warrant and accidentally true belief, op. cit., p. 143.

50 Ibidem, p. 144.

51 Cf. A. PLANTINGA, Alvin Plantinga replies, in: J. L. KVANVIG (ed.), op. cit., p. 316-7.

Ibidem, p. 326-7. 
um maxi-ambiente favorável. "Uma crença $B$ tem autorização só se $M B E$ é favorável ao exercício de poderes cognitivos $E$ pelo qual $B$ é produzida”, só se é o tipo de mini-ambiente ao qual os poderes dos quais $E$ é um exercício são designados, só se é o tipo de mini-ambiente no qual "se pode confiar que" E produz uma crença verdadeira. ${ }^{53}$ De novo, convém precisar o que significa "pode-se confiar que" (can be counted on), isto é, "ser favorável". Plantinga poderia invocar uma teoria de probabilidade, mas sugere pensar em contrafatuais. E não nos contrafatuais (problemáticos) de R. Nozick, ${ }^{54}$ mas naqueles expostos pelo método de "rastreamento cartesiano" esboçado por E. Sosa. Entendo que "rastreamento", segundo Nozick et alii, é uma condição para conhecimento, além de (i) $p$ é verdadeira e (ii) $S$ crê que $p$. Se, originalmente, NOZICK acrescenta os contrafatuais (iii) Se $p$ não fosse verdadeira, $S$ não creria que $p$ ou (iii) não- $p \rightarrow$ não- $S$ crê que $p$, e essa condição subjuntiva só relata em parte a "sensibilidade" da crença que é conhecimento ao valor de verdade de $p$ (à falsidade de $p$ ), de modo que se acrescenta ainda a "sensibilidade" adicional da crença sob um segundo subjuntivo (à verdade de $p$ ), a saber, (iv) Se $p$ fosse verdadeira, $S$ creria que $p$ ou (iv) $p \rightarrow S$ crê que $p$, resta disso, de momento, apenas uma lição para a natureza do conhecimento. Para ter conhecimento, não basta ter crença verdadeira, é preciso tê-la "subjuntivamente". Sob condições (como as i-iv), a crença de $S$ "rastreia" a verdade que $p$, e ter conhecimento é ter uma conexão factual real específica com o mundo: "rastreá-lo". 55

Plantinga se valeu do "rastreamento cartesiano", utilizado por E. Sosa para uma explicação naturalista de função própria, ${ }^{56}$ para explicar o que significa, para um dado exercício $E$ de faculdades cognitivas, "poder-se confiar que" produz uma crença verdadeira. Assim, em se dando no "rastreamento cartesiano" (C) $S$ creria que $P$ sse $P$ fosse verdadeira, tal que (i) $p$ é verdadeira, (ii) $S$ crê que $p$, (iii) $S$ crê que $p \rightarrow p$ é verdadeira, (iv) $p$ é verdadeira $\rightarrow S$ crê que $p$, o mesmo é aplicado para se obter a assim chamada "condição de favorabilidade" (favorability condition) - com as mesmas vantagens desse segundo "rastreamento" sobre o anterior. ${ }^{57}$ Considerando-se uma crença $B$, um exercício $E$ de poderes cognitivos que gera $B$, e o mini-ambiente cognitivo $M B E$ no ela qual é formada, obtém-se a condição de favorabilidade $(\mathrm{CF})$ e, depois, a "condição de resolução" (CR): ${ }^{.58}$

53 Ibidem, p. 327.

54 Essa forma de contrafatuais, cf. abaixo, no texto principal, cria problemas para o conhecimento de proposições necessárias e a possibilidade de disfunção cognitiva em geral; cf. ibidem, p. 327-8. Ademais, mesmo se bem-sucedida com os casos de Gettier, a sua resposta ao ceticismo é insatisfatória; cf. Ernest SOSA, Postcript to "Proper functionalism and virtue epistemology", in: Jonathan L. KVANVIG (ed.), Warrant in contemporary epistemology, p. 275s.

55 Cf. Robert NOZICK, The tracking theory, in: Steven LUPER (ed.), Essential knowledge, p. 135-8.

56 O "contra" está em A. PLANTINGA, Alvin Plantinga replies, in: J. L. KVANVIG (ed.), op. cit., p. 369-70.

57 Como mostrou E. SOSA, Postcript to "Proper functionalism and virtue epistemology", in: J. L. KVANVIG (ed.), op. cit., p. 274s., 276s., a diferença está apenas na terceira condição. As vantagens, porém, são em grande número.

58 Cf. A. PLANTINGA, Alvin Plantinga replies, in: J. L. KVANVIG (ed.), op. cit., p. 328. 
(CF) $M B E$ é favorável para $E$ sse, se $S$ formasse uma crença por meio de $E, S$ formaria uma crença verdadeira. De outro modo: $M B E$ é favorável para $E$ sse, se $S$, num dado mini-ambiente $M$, formasse uma crença por meio de $E, S$ formaria uma crença verdadeira.

(CR) Uma crença $B$ produzida por um exercício $E$ de poderes cognitivos tem autorização - ou: grau de autorização suficiente ao conhecimento - somente se MBE é favorável para $E$. De outro modo: o mini-ambiente favorável, antes rastreado, é uma condição necessária para uma crença autorizada. ${ }^{59}$

Seria possível, agora, reescrever as condições suficientes e necessárias para a crença autorizada e o conhecimento: uma crença tem autorização sse (a) as condições de autorização 1, 3 e 4 se verificam, (b) a (2*) apropriabilidade do maxiambiente se verifica, e (c) a (2**) condição ambiental, incluindo a favorabilidade do mini-ambiente cognitivo, se verifica. Pode-se lembrar que casos de Gettier em geral ainda tinham de ser contornados, dada a versão original das condições 1-4; lê-se, agora, como uma nova estratégia foi montada. E vale também lembrar que a (CR), como apresentada acima, garante que nenhuma crença falsa tem grau de autorização suficiente para o conhecimento, mesmo que o tenha para mera autorização. Assim, a autorização-c e a autorização-p - conforme (a), (b) e (c) - foram bastante aproximadas, e os cenários de Gettier ficaram mais distantes. Ora, não é possível que um mini-ambiente no qual $S$, a partir de um dado exercício $E$ de poderes cognitivos, forma crença $B$ falsa seja favorável ao exercício $E$ que a produz: em tal situação, o contrafatual relevante teria um antecedente verdadeiro e um conseqüente falso. ${ }^{60}$

Retomando a condição necessária $(\mathrm{CF})$, ressalva-se que não é correto que a mera crença verdadeira $B$ gerada por $E$ é suficiente à favorabilidade de $M B E$ - ou: "Se $S$ cresse que $p$ em $M$ a partir de $E$, então $p$ seria verdadeira" é suficiente sem mais para um $M B E$ favorável. A verdade de $p$ e q não basta para a verdade do contrafatual "Se p, então q" - um passo que distancia Plantinga da "semântica usual para contrafatuais". ${ }^{61}$ De fato, se no MBE relevante a Sra. Jones tem o exercício cognitivo de crer que "Eu (Sra. Jones) possuo um Ford funcionando bem", adicionado de que $p$ é verdadeira, isso não pode bastar à verdade de uma instância do condicional em $(\mathrm{CF}){ }^{62}$ Sob certa teoria semântica, para um contrafatual ser verdadeiro, não basta que $(p$ e $-q)$ seja falso. Um contrafatual pode ser falso, mesmo tendo antecedente e conseqüente verdadeiros. É necessário que, mesmo se o mundo tivesse sido levemente diferente, ainda assim não teria sido o caso que $(p$ e $-q){ }^{63}$

59 Ressalva-se, da condição necessária (CR), que crenças que a preenchem se caracterizam apenas por "firmeza suficiente" e, daí, por suficiente grau de autorização, que pode diferir segundo o tipo de crença, mesmo que contando igualmente como conhecimento: " $5+7=12$ " tem mais firmeza que e, daí, mais elevado grau de autorização que "A população do Brasil excede a da Argentina". Cf. A. PLANTINGA, Warrant and accidentally true belief, op. cit., p. 145.

60 Ibidem, p. 144.

61 Cf. A. PLANTINGA, Alvin Plantinga replies, in: J. L. KVANVIG (ed.), op. cit., p. 328.

62 Cf. A. CHIGNELL, Accidentally true belief and warrant, op. cit., p. 448

63 Cf. A. PLANTINGA, Warrant and accidentally true belief, op. cit., p. 144, nota 4; idem, Alvin Plantinga replies, in: J. L. KVANVIG (ed.), op. cit., p. 328. 
Em termos semânticos, o contrafatual "Se p, então q" é verdadeiro só se não há mundo possível suficientemente próximo, no qual $p$ é verdadeiro e $q$ é falso. ${ }^{64}$ Parecem existir mundos suficientemente próximos, nos quais a Sra. Jones em $M$, por $E$, crê que $B$ (p é verdadeira), mas $B$ é falsa (q é falsa), tal que o $M B E$ da Sra. Jones é desfavorável, e a sua crença não constitui conhecimento. Note-se que $B$, aplicada ao exemplo, poderia ser uma crença básica falsa com relação de inferência com outra crença $C$ verdadeira ("O meu Ford, que estacionei há alguns minutos, encontra-se lá fora"; logo, "Eu (Sra. Jones) possuo um Ford”), figurando um cenário de Gettier, ou apenas uma crença básica falsa sem qualquer relação de inferência ("Eu (Sra. Jones) possuo um Ford"), podendo haver, é claro, muitos mundos possíveis "próximos" para ambas as crenças. ${ }^{65}$ Não vejo, enfim, contra Chignell, como inquietante a afirmação de Plantinga de que o significado de "suficientemente próximo" é "vago". ${ }^{66}$ Isso, por exemplo, não torna problemático aceitar que o mundo do Ford estacionado demolido (e de crença verdadeira acidentalmente) é suficientemente próximo do mundo do Ford estacionado intacto (e de crença verdadeira autorizada). Aqui, um mundo suficientemente próximo de outro pode ser um mundo de mesmo maxi-ambiente que o outro, para um exercício $E$ de poder cognitivo para crer que $B$, mas com um mini-ambiente (um ambiente maximamente especificado daquele maxi-ambiente), para um exercício $E$ de poder cognitivo para crer que $B$, diferente do outro: para um ou para outro há favorabilidade ou desfavorabilidade quanto ao mini-ambiente em que se dá um exercício $E$ de poderes cognitivos respectivos a $M$ para $B$ (estados de coisas corriqueiros ou estados de coisas bizarros, no caso da Sra. Jones), e há favorabilidade quanto ao maxi-ambiente respectivo aos poderes cognitivos que lhe são relevantes (circunstâncias corriqueiras da memória, da percepção e do testemunho de outros sobre o fato de uma senhora adulta possuir e de costume dirigir um Ford funcionando bem).

Na mesma linha, é relevante a crítica de que Plantinga, mesmo com o esforço de tornar autorização-p coextensiva à autorização-c, não explana "similaridade suficiente" (com moderada diferença) entre ambientes cognitivos, em que ( $p$ e $-q)$ não é o caso em nenhum deles, e ( $p$ e q) continua sendo o caso nos mesmos. ${ }^{67}$ Pareceria que a similaridade suficiente permitiria a produção de crenças falsas, a menos que incluísse, na sua definição, "obtenção da verdade" como condição necessária. Se "obtenção de verdade" não é feita condição necessária àquela, nenhuma especificação de similaridade suficiente satisfaz a exigência de que não existem crenças autorizadas-p falsas. Ora, segue-se disso que (i) nenhum ambiente cognitivo é suficientemente similar àquele ao qual um mecanismo cognitivo particular foi designado, sendo conseqüência desse fato que (ii) nenhuma crença é

Ibidem, p. 329

65 Cf. A. CHIGNELL, Accidentally true belief and warrant, op. cit., p. 448

${ }^{66}$ Cf. A. PLANTINGA, Alvin Plantinga replies, in: J. L. KVANVIG (ed.), p. 329; A. CHIGNELL, Accidentally true belief and warrant, op. cit., p. 448.

67 Cf. GREENE and BALMERT, Two notions of warrant and Plantinga's solution to the Gettier problem, op. cit., p. 138-9. 
autorizada-p. A obtenção da verdade como condição necessária de um ambiente cognitivo similar implica que os sujeitos foram designados a produzir crenças só sob circunstâncias que jamais originam crenças falsas (sic!): "Qualquer crença perceptual verdadeira, produzida num ambiente cognitivo no qual uma crença perceptual falsa poderia ter sido produzida, não seria, de acordo com esta estratégia, uma crença autorizada-p", ${ }^{8}$ o que evidencia que a maioria das crenças humanas não teria autorização-p. É verdade que Plantinga não explicita a similaridade suficiente (com moderada diferença) entre ambientes cognitivos. De qualquer modo, incluindo a obtenção da verdade como condição necessária, a seguinte reflexão torna as conseqüências (i) e (ii) falsas: um ambiente cognitivo é suficientemente similar (com moderada diferença) a outro, satisfazendo a explanação do contrafatual semântico da (CF) "Se $p$, então q", sse ele admite, para o módulo cognitivo envolvido no exercício $E$ de crença $B$, o mesmo maxi-ambiente relevante e não contém nenhum mini-ambiente desfavorável ao exercício $E$ de produção da mesma crença $B$.

\section{Condição de favorabilidade e condição de resolução revisitadas}

Antes de prosseguir com "revisitas" ao novo quadro das condições de autorização-p, é necessário realizar alguma interpretação. Primeiro, a condição de ambiente cognitivo sob (CF) e (CR), com as cláusulas restantes, propicia um grande atenuamento da força dos exemplos de Gettier-Klein, mas não uma solução total. Plantinga segue admitindo cenários de irresolução, dada a reformulação do conjunto. Veja-se o exemplo parafraseado: ${ }^{69}$

Recebo uma caixa, na qual há um vaso. Por causa de um arranjo especular, ao abri-la não vejo diretamente o vaso, mas a sua aparência refletida, mesmo que forme a crença firme e verdadeira de que há, ali, um vaso. As condições de autorização, aqui, são preenchidas, bem como (CR): se eu formasse uma crença sobre o tópico da proposição focal desse mini-ambiente, pelo exercício $E$ de poderes cognitivos, formaria uma crença $B$ verdadeira. É uma situação na qual tal exercício de poderes cognitivos conta como gerando uma crença verdadeira. É ela conhecimento? Se eu soubesse do arranjo, por ser um inspetor de caixas desse tipo, com a tarefa de encontrar as poucas nas quais o vaso foi deixado de fora, talvez tenha conhecimento. Se não sei do arranjo especular, tenho eu conhecimento? Não estabeleço a "cadeia causal" de formação de crença de modo "desviante"?

Pareceria que, para Plantinga, a tarefa da epistemologia chega a limites ali onde a precisão das condições de resolução do ambiente cognitivo tem limites ou "áreas de vagueza nas penumbras do conceito de conhecimento". ${ }^{70}$ A contratarefa é o esforço por precisão, incluindo uma margem mais extensa de casos de Gettier - cf. abaixo as revisitas.

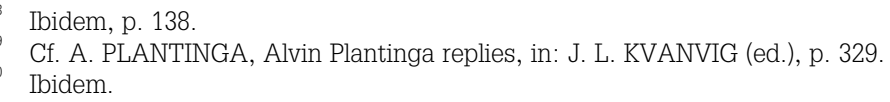


Em segundo lugar, creio que as distinções entre maxi- e mini-ambiente cognitivo têm tal peso na teoria de autorização por função própria que, mesmo que a condição ambiental sob (CF) e (CR) seja verdadeira e, nos termos do externalismo, possível como cláusula de autorização e conhecimento, precisa ser protegida de certas ameaças. Afinal, o fato de haver entre eles uma comparação a modo de tipo (de ambiente cognitivo favorável) e instância particular (de ambiente cognitivo favorável), na qual o peso de condição necessária à autorização e conhecimento está na instância particular, poderia impor ao conhecimento como crença verdadeira autorizada o rótulo de "casuísmo" - por graça de Deus ou do mundo, isto é, sse (CF) se dá, por alguma "graça”. E isso tem notório vínculo com o perigo cético que ronda a teoria de autorização por função própria - ao menos para certos módulos cognitivos e certos tipos de crença/conhecimento. Klein afirmara que, se a resposta ao contra-exemplo da Sra. Jones fosse que ela não estava, afinal, autorizada a crer possuir um Ford em bom funcionamento, isso levaria ao ceticismo acerca do passado - sobre crenças, presume-se, geradas por um exercício $E$ do poder cognitivo chamado "memória perceptual", ou "memória perceptual recente". Ora, tinha-se visto que, num exemplo de Gettier-Klein, o cenário esperado e o cenário desviante eram eqüipolentes, com respeito à conformação idêntica dos mecanismos cognitivos, exercendo a sua função própria. Tornar-se-ia forçoso assentir que a Sra. Jones não estaria autorizada a crer que possui um Ford funcionando bem, mesmo quando tudo fosse tal como em geral crê ser, caso a caso - e em casos análogos sobre crenças de memória perceptual. Céticos aceitariam a oportunidade de, a partir da condição (2), fazerem dos cenários de Gettier-Klein hipóteses céticas relevantes. ${ }^{71}$ Como a teoria de autorização por função própria lidaria com isso?

Neste estudo, segue-se o esforço por precisão das condições de favorabilidade e resolução do ambiente cognitivo. Portanto, analiso revisitas à (CF) e à (CR). Afinal, é a autorização-p provida de (CF) e (CR) na cláusula (2) que deveria superar o problema de Gettier, sendo coextensiva à autorização-c. Por isso, críticas como a de Greene e Balmert, de que Plantinga falha em dar critério de identificação de ambiente cognitivo próprio a um módulo cognitivo particular, já são ineficazes. ${ }^{72}$ Ora, o ambiente cognitivo no qual uma crença $B$ falsa é gerada é diferente de um no qual a mesma crença $B$ verdadeira e autorizada-p é formada, mesmo quando circunstâncias de maxi-ambiente de produção de crenças são idênticas. Não há problema teórico para Plantinga lembrar que a crença B falsa de Frege, de que para toda propriedade há o conjunto que contém exatamente as coisas que apresentam a propriedade, foi produzida num ambiente cognitivo similar àquele em que os demais axiomas verdadeiros de teoria dos conjuntos foram gerados (contando que estavam autorizados-p a ele). Pode-se dizer que foram gerados nas mesmas circunstâncias de

1 Cf. P. KLEIN, Warrant, proper function, reliabilism, and defeasibility, in: J. L. KVANVIG (ed.), op. cit., p. 107-8.

72 Cf. GREENE and BALMERT, Two notions of warrant and Plantinga's solution to the Gettier problem, op. cit., p. 137s. 
maxi- e em distintas circunstâncias de mini-ambiente. Ademais, nada indica que se trata, no contra-exemplo, de um mini-ambiente cognitivo desfavorável, mas de mera ausência de função própria ou adequado módulo cognitivo àquela crença lógicomatemática e situação.

3.1 Tomo como primeira crítica de impacto aos reparos à condição do ambiente epistêmico o argumento de T. M. Crisp, que afirma a contínua vulnerabilidade daquela às dificuldades de Gettier. Mina-se a "favorabilidade contrafatual" - a (CF) de Plantinga, ${ }^{73}$ sugerindo uma favorabilidade que um mini-ambiente tem, quanto a um dado exercício de poder cognitivo $E$, sse os outputs de $E$ em $M$ não são acidentalmente verdadeiros. Trata-se de uma noção mais geral da condição de favorabilidade, a "favorabilidade-g":

(CFg) Um mini-ambiente $M E$ tem favorabilidade-g para um exercício $E$ de poderes cognitivos =df. $S$ forma uma crença por meio de $E$ em $M E$, e a crença de $S$ não é acidentalmente verdadeira. ${ }^{74}$

Segundo Plantinga, seria o caso que a sua (CF), com as demais condições de autorização, bastaria para (CFg). Para medir a força dessa pretensão, deve-se conferir o exemplo do anual "concurso de adivinhação-do-número-de-ameixas-nopote" da cidade: ${ }^{75}$

Imagine o caso em que o seu tio organiza o concurso anual de adivinhação do número de ameixas no pote. Um amigo seu, muito matreiro, toma, por boa autoridade, que o pote contém 138 ameixas, e lhe conta esse segredo. Sem o seu conhecimento e o do seu amigo, ocorre que o número secretado é incorreto. Imagine, então, que o seu tio ficou doente, acometido de febre cerebral incomum, vindo a acreditar que o destino da nação depende de você vencer o concurso. Ele não consegue sequer se lembrar do número de ameixas no pote. Por isso, esvazia-o e enche-o de novo, com o exato número de ameixas indicado no bilhete de entrada do concurso que você possui. No memorável dia, você participa com a firme convicção de que o pote contém 138 ameixas. De fato, contém essa quantidade. A sua crença, porém, é verdadeira por acidente: se o seu tio não tivesse ficado febril, a sua crença teria sido falsa. Esse mini-ambiente não tem favorabilidade-g. No entanto, ele tem favorabilidade segundo (CF), incluindo o contrafatual: Se você fosse adivinhar que o pote continha o número $n$ de ameixas, então o seu tio teria enchido o pote com o número $n$ de ameixas.

Conseqüência disso é que todos os mundos próximos, nos quais o exercício $E$ de poderes cognitivos ocorre em tal mini-ambiente, são mundos nos quais $E$ produz crença verdadeira. O mini-ambiente tem $(\mathrm{CF})$, e a crença inclui as condições de autorização. Daí, o dito reparo falha: (CF) não é, com as demais condições de autorização, suficiente para (CFg), pois não superou os problemas de Gettier. A crença, acima, satisfaz cada condição da versão corrigida, mas carece de autorização-c, pois é só acidentalmente verdadeira. ${ }^{76}$

73 Posteriormente, A. PLANTINGA, Warranted Christian belief, p. 159 (nota 46) e p. 160, devendo o ponto ao mesmo T. M. Crisp, revela, ainda que muito resumidamente, pouca confiança na (CF) apresentada como remédio; cf. abaixo, sob 4.

74 Cf. T. M. CRISP, Gettier and Plantinga's revised account of warrant, op. cit., p. 46.

75 Ibidem, p. 46-7.

Ibidem, p. 47 
T. M. Crisp argumenta, porém, que um mini-ambiente pode ser favorável a um exercício $E$ de poder cognitivo. Diga-se que $P(p / q)$ é "a probabilidade epistêmica de $p$, dado $q$ "; diga-se que $q$ confirma $p$ a $S$ sse $P(p / q \wedge k)>P(p / k)$, sendo $k$ a conjunção das crenças de fundo de $S$. E uma proposição $p$ anula uma crença $b$ a $S$ sse $P(b / p \wedge k)$ $<P(b / k)$, e $P(b / p \wedge k)<n$, "em que $n$ é um número real, representando o ponto no qual um ser humano com faculdades funcionando propriamente cessaria de crer que $b$ ". Diga-se, por fim, que $p$ é um anulador-não-anulado de $b$ a $S$ sse $p$ anula $b$ a $S$, e não há proposição verdadeira $q$ tal que (i) $q$ não anula nem $b$ nem não-b a $S$, e (ii) $P(b / p \wedge q \wedge k)>n$. A partir disso, define-se um mini-ambiente desfavorável: " $M E$ é um mini-ambiente desfavorável ao exercício $E$ do poder cognitivo de $S$ resultando na crença $b=$ df. existem proposições $p$ e $q$, nenhuma das quais são cridas por $S$, tal que" (a) $M E$ acarreta não-p e $q$, (b) $P(p / k)>P(q / k)$, (c) ambos $p$ e q confirmam $b$ a $S$ e (d) não-p é um anulador não-anulado de $b a S$, e não-q não anula $b$ a $S$. Essas condições são satisfeitas no exemplo da Sra. Jones. Ou: $b=$ "Eu (Sra. Jones) possuo um Ford funcionando bem"; $p=$ "Não é o caso que o meu Ford foi destruído"; $q=$ "Eu recém venci o concurso do Ford". A partir daí, define-se um mini-ambiente favorável a um dado exercício de poder cognitivo $E$ : (CF") " $M E$ é favorável ao exercício $E$ dos poderes cognitivos de $S=$ df. $M E$ não é desfavorável a $E$ ". Com isso, ao obter-se uma versão que não é vítima dos casos de Gettier dados, corrige-se a abordagem de Plantinga, interpretando-se (CR) em termos de $\left(\mathrm{CF}^{\prime}\right)$, e não em termos de $(\mathrm{CF}) .^{77}$ Abaixo, criticarei o contra-exemplo de T. M. Crisp e indicarei lacunas na solução que sugere em termos de probabilidades.

3.2 Também T. M. Botham propõe contra-exemplos à (CF) de Plantinga, ofuscando o seu mérito em diminuir os problemas de Gettier e servir, junto com a (CR), à determinação de autorização e conhecimento. ${ }^{78} \mathrm{O}$ crucial é: em virtude do que um mini-ambiente $M B E$ é favorável ao exercício de poderes cognitivos $E$ de $S$ ? Para tanto, retoma-se o seguinte retoque de Plantinga à falta de resolução da condição ambiental original:

(CF2) $M B E$ é favorável a $E$ somente se não há estado de coisas $S$ incluído em $M B E$, mas não em $D M B E$, tal que a probabilidade objetiva de $B$ com respeito à conjunção de $D M B E$ e $S$ cai abaixo de $r$, em que $r$ é algum número real representando uma probabilidade razoavelmente alta.

Assume-se, aqui, que podem existir traços epistemicamente relevantes do ambiente do sujeito que não são detectáveis por $E$. Distingue-se entre (i) estados de coisas incluídos em $M B E$ que são detectáveis cognitivamente por $E$ - um DMBE e (ii) estados de coisas incluídos em $M B E$ que $E$ não consegue detectar. Sabe-se que

Ibidem, p. 48-9

Cf. T. M. BOTHAM, Plantinga and favorable mini-environments, op. cit., p. 433-4.

79 Cf. A. PLANTINGA, Warranted Christian belief, 2000, p. 160. A. CHIGNELL, Accidentally true belief and warrant, op. cit., p. 448, afirma que Plantinga, ali, abandona a análise contrafatual de favorabilidade em favor de uma que focaliza condições dentro do mini-ambiente cognitivo ameaçado por exemplos de Gettier. Essencialmente, Plantinga busca contornar a embaraçosa multiplicação de contra-exemplos para a (CF) em termos de contrafatuais. Cf. abaixo, sob 4. 
casos de Gettier são tais que um MBE se mostra desfavorável sob (CF), descreditando (CR): por isso, não se tinha, no contra-exemplo básico, conhecimento de "Eu (Sra. Jones) possuo um Ford funcionando bem". Por semelhante modo, certo candidato a $S$, com um $D M B E$, torna a probabilidade objetiva de $B$ não-razoavelmente alta, caracterizando a negação de (CF2) - em que, por exemplo, B1 "Eu (Sra. Jones) possuo um Ford funcionando bem" e $S 1=$ "O Ford da Sra. Jones foi destruído pelo caminhão do lixo". Botham quer mostrar que (CF2) é lacunar, pois torna desfavoráveis muitos MBES intuitivamente favoráveis. ${ }^{80}$ Considere-se: ${ }^{81}$

Ao invés de construir fazendas de fachada de tamanho real, os habitantes de uma região do interior de Wisconsin manufaturam fazendas tão pequeninas que o transeunte não pode vê-las. Talvez as fazendas em miniatura tenham somente duas polegadas de altura, construídas para serem adequadas a comunidades de formigas. Quando alguém dirige através desse território anômalo, vê uma das únicas fazendas reais e crê na proposição "Aquela é uma fazenda bonita".

Aqui, o sujeito claramente tem conhecimento; porém, há um estado de coisas S2 - "Haver muitas simulações de fazenda na região" - que, com DMBE2, torna a probabilidade objetiva da crença B2 do sujeito não-razoavelmente alta. Por (CF2), o MBE2 é desfavorável ao E2, e (CF2), conjugada com (CR), acarreta que não se tem conhecimento. Porém, o sujeito sabe de fato que "Aquela é uma fazenda bonita”. Logo, (CF2) é inadequada por tornar desfavorável um MBE intuitivamente favorável. Botham crê que se pode responder a esse e a outros exemplos símiles, por um lado, negando que são casos paradigmáticos de conhecimento - são talvez casos limítrofes -, ao que se objetaria, então, que com aquilo se assumiria não haver casos claros de conhecimento, quando há estados de coisas equívocos quaisquer quanto a um exercício de poderes cognitivos. ${ }^{82}$ Por outro lado, uma resposta alternativa aceita que o caso acima é uma instância de conhecimento. Assim, deve-se modificar (CF2), para lidar com estados de coisas equivocados candidatos a $S$ :

$\left(\mathrm{CF} 2^{*}\right) M B E$ é favorável a $E$ só se, para todo estado de coisas $S$, incluído em $M B E$, mas não em $D M B E$, tal que a probabilidade objetiva de $B$ quanto à conjunção de $D M B E$ e $S$ cai abaixo de $r$, há outro estado de coisas $S^{*}$, tal que: (1) $M B E$ inclui $S^{*}$; (2) a conjunção de $S^{*}$ e $D M B E$ não acarreta $B$; (3) $S^{*}$ inclui $S$; (4) não é o caso que a probabilidade objetiva de $B$ quanto à conjunção de $D M B E$ e $S^{*}$ cai abaixo de $r^{83}$

$\left(\mathrm{CF}^{*}\right)$ vai ao encontro do seguinte caso, introduzido contra (CF2): B2= "Aquela é uma bonita fazenda"; $S 2=$ "Há muitas fachadas de fazenda na região"; $S^{*} 2=$ "S2 e é o caso que todas as simulações de fazenda são cerca de duas polegadas de altura". Central é que, mesmo que a probabilidade objetiva de $B$ não seja razoavelmente alta quanto à conjunção de $S$ e $D M B E$, ela o é na conjunção de

80 Cf. T. M. BOTHAM, Plantinga and favorable mini-environments, op. cit., p. 435s.

Para o exemplo original completo das "fazendas de fachada", deveras recorrente, cf., por exemplo,

A. PLANTINGA, Warrant and proper function, p. 32-3.

82 Cf. T. M. BOTHAM, Plantinga and favorable mini-environments, op. cit., p. 436-7.

83 Ibidem, p. 437. 
$S^{*}$ e DMBE. O transtorno, porém, é que (CF2*) falha, agora, em casos de Gettier aos quais (CF2) foi proposta originalmente, pois $\left(\mathrm{CF}^{*}{ }^{*}\right.$ "não implica que miniambientes intuitivamente desfavoráveis são desfavoráveis". O exemplo $B 2=$ "Aquela é uma fazenda bonita", $S 2=$ "Há muitas fachadas de fazenda na região" e $S^{\star} 2=$ " $S 2$ e é o caso que, de todas as estruturas de fazenda da região, só as fazendas de fachada [melhor: quase só as fazendas de fachada, de um total suposto de cem estruturas tipo fazendal ${ }^{84}$ estão de frente para a rodovia" ilustra a inadequação de $\left(\mathrm{CF} 2{ }^{*}\right) .{ }^{85}$ Este e exemplos semelhantes - como B1= "Eu (Sra. Jones) possuo um Ford funcionando bem", $S 1=$ "O Ford da Sra. Jones foi destruído pelo caminhão do lixo" e $S^{*} 1=$ "S1 e é o caso que o bilhete premiado do concurso Ford da companhia pertence à Sra. Jones" - são casos de Gettier, e a crença $B$, em cada um, é verdadeira só acidentalmente. ${ }^{86}$

Em resumo, dado que $B$, nos casos acima, é verdadeira, há estados de coisas que a tornam verdadeira e estados de coisas sobre os quais ela é provável de modo não-trivial. Daí, mesmo que a probabilidade objetiva de $B$ em DMBE e $S$ seja não-razoavelmente alta, há sempre um estado de coisas mais amplo $S^{*}$ que inclui $S$ e, ligado a $D M B E$, torna a probabilidade objetiva de $B$ suficientemente alta. Ao mesmo tempo, $\left(\mathrm{CF}^{*}\right)$, se útil para uma contra-intuição, não consegue mostrar que certos mini-ambientes intuitivamente desfavoráveis de fato o são. Portanto, para especificar as condições necessárias da cláusula de favorabilidade, requer-se ainda alguma $\left(\mathrm{CF}^{* \star}{ }^{\star *}\right.$ que contorne exemplos de Gettier. ${ }^{87}$ Abaixo, argüirei que, na crítica de T. M. Botham a conseqüências de (CF2), fecham-se os olhos a elementos teóricos complementares a essa forma da condição de favorabilidade, presentes na teoria de autorização por função própria de Plantinga e a partir dos quais uma formulação geral mais satisfatória da mesma condição e da mesma teoria pode ser buscada.

3.3 Também A. Chignell sugere a reformulação de $(\mathrm{CF} 2){ }^{88}$ Eis um exemplo:

Johnson há pouco começou a observar pássaros e estudou ornitologia por livros e audição do canto de espécies. Nunca tinha visto um pardal canoro antes, mas está familiarizado indiretamente com as suas características. Não sabia que tal espécie sofrera recentemente de vírus e morte em massa, restando apenas dois deles no continente. $\mathrm{O}$ pardal de Lincoln, muito parecido com o anterior, não foi afetado pelo vírus, havendo muitos deles na região de Johnson. Johnson, na floresta, crê seguir um pardal canoro. Trata-se de um dos dois sobreviventes no continente. Johnson o estuda e confirma os seus traços. Chega a um assentimento, com grau suficiente de autorização, sobre a proposição de que o pássaro que observa é um pardal canoro, e adiciona isso à sua lista de pássaros observados.

84 Correção do exemplo que me parece obviamente necessária.

Cf. T. M. BOTHAM, Plantinga and favorable mini-environments, op. cit., p. 438-9. Botham, cf. ibidem, p. 440, nota 15, afirma usar, aqui, algo como anuladores epistêmicos e anuladores ilegítimos para lidar com contra-exemplos de Gettier.

86 Ibidem, p. 439.

87 Ibidem, p. 439.

88 Cf. A. CHIGNELL, Accidentally true belief and warrant, op. cit., p. 449. 
Se, de novo, as condições 1-4 de Plantinga (sem o primeiro reparo ou (CF)) são preenchidas, pelo segundo reparo ou (CF2) o mini-ambiente cognitivo não é favorável. Nele, a crença $B$ não teria autorização suficiente ao conhecimento visto que há estado de coisas $S$ conjugando a quase extinção do pardal canoro e a grande semelhança dos ainda numerosos pardais de Lincoln, que está incluído em $M B E$, porém não em $D M B E$, além de a probabilidade objetiva de $B=$ "Aquele pássaro é um pardal canoro", dada a conjunção de DMBE e $S$, cair abaixo de $r$. Porém, há forte intuição de que $B$ é conhecimento para o sujeito observador, não sendo mera acidentalidade. Contra-exemplos desse tipo mostram que (CF2) falha em isolar e excluir só os tipos de crenças típicas de casos de Gettier. Assim, (CF2) elimina muitas crenças intuitivamente verdadeiras e que são casos de conhecimento. ${ }^{89}$

A mácula nos reparos de Plantinga é que o mini-ambiente ideado é sempre específico demais. Como definido, não haveria duas crenças com o mesmo $M B E$. Sendo o $M B E$ específico a uma crença, é impossível que a análise da (CF) apele a outras crenças formáveis no mesmo mini-ambiente. Em (CF), Plantinga apela a mundos próximos, nos quais a mesma crença é formada em circunstâncias levemente diferentes. Chignell propõe que os problemas envolvendo crenças verdadeiras acidentalmente são solucionáveis só por apelo a crenças diferentes formáveis nas mesmas circunstâncias. Isso traz à autorização por função própria menos vulnerabilidade a casos de Gettier. Redefine-se, pois, o MBE:

$\left(M B E^{*}\right)$ Um mini-ambiente é um estado de coisas maximamente específico em to, em que to é o instante justamente anterior ao tempo $t$, no qual o sujeito forma uma crença $B .^{90}$

A partir disso, a favorabilidade de $M B E$ é relativa não só a uma crença que o sujeito pode formar em $t$ (muito estrito), e tampouco a todas as crenças produzíveis por uma das faculdades do sujeito em $t$ (muito amplo), mas a todas as crenças que podem ser produzidas por uma das suas faculdades, sobre certo objeto intencional em $t$. Daí, define-se $\left(\mathrm{CF}^{\star *}\right)$ :

(CF2*') Um mini-ambiente $M E$ é favorável a um exercício $E$ de faculdades cognitivas $F$ do sujeito, acerca de um objeto particular $O$ naquele ambiente, só se qualquer crença $B$ sobre $O$ que o sujeito poderia formar pelo exercício $F$ em $M E$ é tal que, se $B$ preenche as outras condições de autorização, então é objetivamente provável - no espírito da condição original (4) - que $B$ seja verdadeira. ${ }^{91}$

Em (CF2*'), dá-se um conjunto de crenças que inclui todas as crenças autorizadas que o sujeito poderia formar sobre $O, \operatorname{com} F$, em $M E$. Excluem-se potenciais contra-exemplos, nos quais o sujeito simplesmente formaria, em sua maior parte, crenças falsas, mas com alguma autorização, sobre $O, \operatorname{com} F$, e nos quais uma ou duas crenças verdadeiras e autorizadas, geradas por $F$ sobre $O$, surpreenderiam

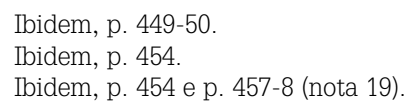


intuitivamente como conhecimento. (CF2*') exclui crenças verdadeiras acidentalmente. No caso da Sra. Jones, o O relevante é o Ford ganho no concurso, e qualquer crença de memória perceptual que ela formasse sobre $O$, preenchendo as outras condições de autorização, teria, então, baixa probabilidade objetiva de ser verdadeira. O conjunto incluiria "Eu (Sra. Jones) comprei o Ford há oito anos", "O meu Ford tem mais de 50.000km rodados", "O meu Ford está estacionado, lá fora, como o deixei há cinco minutos", etc., que, dado o contra-exemplo, são em sua maioria falsas. Claramente, por (CF2*'), uma ou duas crenças verdadeiras no conjunto, incluindo "Eu (Sra. Jones) possuo um Ford funcionando bem", são produzidas num $M E$ desfavorável. Lembrando-se da (CR), entende-se que uma crença como "Eu (Sra. Jones) possuo um Ford funcionando bem" carece de autorização suficiente ao conhecimento. Por outro lado, a crença de Johnson sobre o pardal canoro é formada num $\mathrm{ME}$ conforme à ( $\left.\mathrm{CF}^{*}{ }^{*}\right)$. Refletindo sobre o conjunto de crenças que Johnson poderia formar sobre o pássaro, a partir das suas faculdades perceptuais, ele incluiria "O pardal está agarrado a um galho", "O pássaro gorjeia suavemente", "Aquela é uma plumagem distintiva", etc., em sua maioria verdadeiras. Por (CF2*') e (CR), a crença verdadeira de Johnson, "Aquele pássaro é um pardal canoro", tem autorização suficiente ao conhecimento. ${ }^{92}$ Abaixo, direi que é preciso esclarecer o quanto a observação de (CF2*'), para a crença verdadeira e o conhecimento, depende do sucesso das (CF) e (CF2) originais.

\section{Condição ambiental reconquistada e conclusão}

A teoria de autorização epistêmica de Plantinga tem segmentos sofisticados, como a versão do externalismo de M. Bergmann, cuja base é a função própria das faculdades cognitivas dos sujeitos epistêmicos. A abordagem de Bergmann sobre "justificação" considera as condições originais 1-4 de Plantinga, junto com a condição (5), a "condição de ausência de anulador": "S não toma $B$ como sendo anulada". ${ }^{93}$ Esta condição não seria satisfeita por aquelas quatro primeiras, independentemente da admissão, por Plantinga, de que autorização depende do funcionamento próprio de sistemas de anuladores. ${ }^{94} \mathrm{Na}$ verdade, Bergmann exclui a condição (2) de Plantinga, a condição ambiental, pois, com a sua retirada, o externalismo de função própria não acarreta confiabilidade, por conseguinte, tampouco problemas congênitos do confiabilismo, como a objeção do demônio maligno. ${ }^{95}$

Ibidem, p. 455 e p. 457-8 (nota 19).

3 Cf. Michael BERGMANN, Externalist justification without reliability, in: Ernest SOSA and Enrique VILLANUEVA (eds.), Philosophical Issues 14 - Epistemology, p. 44

Ibidem, p. 44s. e p. 57, notas 35-37. Cf. A. PLANTINGA, Warrant and proper function, p. 41; idem, Warranted Christian belief, p. 357-66.

95 Cf. M. BERGMANN, Externalist justification without reliability, in: E. SOSA and E. VILLANUEVA (eds.), op. cit., p. 45. Cf. acima, sob 3, a segunda das minhas duas "interpretações". 
Tampouco Plantinga cessou as desconfianças sobre a condição ambiental relida segundo (CF) e (CF2) - chegou a incentivá-las. ${ }^{96} \mathrm{O}$ desabono de (CF), obra destrutiva da qual T. Crisp é co-autor, significa para Plantinga que o próprio contrafatual relevante pode ser verdadeiro "só por acidente". Apenas com a condição da favorabilidade por interpretação contrafatual, a ameaça da acidentalidade sobrevive. Creio que Plantinga endossaria a afirmação de que (CF) não basta para (CFg). Para tanto, exemplo seu de que se tem notícia, adicionando, junto com a crítica de T. Crisp, motivação para uma nova análise da condição de favorabilidade em termos de probabilidade, pode ser recontado assim: ${ }^{97}$

Pensemos de novo nos habitantes do interior de Wisconsin, que, na permanente tentativa de dar a tudo a melhor aparência, erguem muitas fazendas de fachada. Dirigindo pela região numa manhã do início de setembro, quando há muita neblina na paisagem, olho à direita e vejo uma fazenda real. De fato, todas as fazendas na proximidade são de fachada, e em número muito maior do que as reais. As de fachada estão ocultadas pela neblina matinal. Digo, então, "Aquela é uma fazenda bonita!”. É uma crença verdadeira. E o contrafatual relevante também é verdadeiro, por causa do modo como as fazendas de fachada estão encobertas. ${ }^{98}$

O contrafatual relevante, presume-se "Se o viajante (o sujeito epistêmico) cresse que $B$ pelo exercício $E$ em $M$, então $B$ seria verdadeira", interpretado por análise semântica de contrafatuais, é verdadeiro, porém a crença, assim afirma Plantinga taxativamente, não tem, dada a acidentalidade da sua produção, autorização bastante ao conhecimento. ${ }^{99}$ Antes de comentar tal veredicto, lembro que, seja sob a estratégia de $(\mathrm{CF})$, seja sob a de (CF2), as impressões de Plantinga não são animadoras: ainda que a (CF2) pareça promissora, confia-se nela tanto quanto se cogita que, com o tempo, talvez não se possa dizer sobre a resolução da condição ambiental nada além de que o seu rendimento máximo é ditar que o mini-ambiente deve ser favorável. Isso segue em acordo com a idéia de que, dadas as condições 1-4 originais, é-se forçado a reconhecer que as capacidades cognitivas humanas não são "maximamente efetivas", o que não significa apenas certa limitação natural fática, mas certa "inclinação" ao erro. A linguagem de "inclinação" ${ }^{100}$ é imprecisa, pois parece implicar "tendência" natural das faculdades cognitivas ao erro; o melhor é dizer que o esquema de Plantinga insinua "abertura" ou "irresolução" inevitável das faculdades cognitivas, que se atribui face à comparação com a cláusula (2) e já configura condição suficiente ao erro. ${ }^{101}$ De qualquer modo, o que se quer dizer com isso é o mesmo: num maxi-ambiente favorável, é possível haver mini-ambientes cognitivos a um exercício de faculdades nos quais uma crença verdadeira, se formada, é formada por

96 Cf. acima, nota 73. As pesquisas de T. M. Botham e A. Chignell têm a recomendação explícita de A. Plantinga.

97 Afinal, é notório que T. Crisp preenche a sua (CFg) com uma interpretação segundo probabilidade. Cf. acima, sob 3.

98 Cf. A. PLANTINGA, Warranted Christian belief, p. 159-60.

99 Ibidem, p. 160.

${ }^{100}$ Ibidem, p. 160-1.

${ }^{101}$ Cf. acima, sob 3, a primeira das minhas duas "interpretações". Não sei se Plantinga, cf. ibidem, p. 161, tem tal parecer em vista, ao afirmar, sem comentário, que o grau de autorização necessário ao conhecimento depende, em alguma medida, de circunstâncias e contexto. 
acidente, motivo pelo qual não tem neles autorização suficiente ao conhecimento. Para crença constituir conhecimento, aceita é claro com firmeza suficiente, exigir-seia a (CF2) e, daí, uma nova (CR). Cabe, agora, perguntar, assumindo essa margem de incerteza comum às duas condições de favorabilidade: (i) O juízo sobre a (CF) é mesmo correto? (ii) $\mathrm{O}$ que se pode realmente reivindicar da (CF2)?

1. Se estou certo, Crisp e Plantinga pretendem, com os seus contra-exemplos a $(\mathrm{CF})$, mostrar que mini-ambientes assim favoráveis ainda não eliminam a acidentalidade, em se detectando esta por probabilidade. Sim, pois, segundo a interpretação contrafatual da favorabilidade, ambas as crenças, nos exemplos, são autorizadas e constituem conhecimento. Porém, segundo o conteúdo de (CF2), a crença $B$, em cada caso, não atingiria em $D M B E$, conjugado a $S$, uma probabilidade objetiva razoavelmente alta. Nos seus próprios termos, nos dois exemplos, a (CF) cumpre o seu papel e há, segundo as condições dadas, crença autorizada e conhecimento. Ocorre, porém, que a acidentalidade por probabilidade é compatível com a favorabilidade de mini-ambientes cognitivos por interpretação contrafatual. Até onde vejo, isso é um problema apenas para a probabilidade, não para contrafatuais. Como, afinal, uma concepção de acidentalidade cognitiva por probabilidade tem influência sobre favorabilidade por semântica de contrafatuais?

Naturalmente, essa compatibilidade agride a intuição sobre a natureza do conhecimento, que ou bem é ou parte de crença verdadeira autorizada básica, formada sem qualquer modo de acidentalidade. Em função disso, parece-me mais natural dizer que a (CF2) deve ser acrescentada à (CF), em casos em que, apesar do funcionamento da última, é contra-intuitivo admitir que inexiste acidentalidade na obtenção da crença verdadeira. E como se verá abaixo, o inverso pode ser dito de (CF2), ali onde é contra-intuitivo dizer que, cumprida a (CF2), a acidentalidade não mais existe na obtenção da crença verdadeira, isto é, onde a (CF) deve ser acrescentada à (CF2). O que se quer obter, agora, é sem dúvida não-acidentalidade/favorabilidade e pró-intuitividade de crenças verdadeiras, pela aplicação conjunta de (CF) e (CF2). É notório que, nesse caso, introduz-se a máxima de eliminar a contra-intuitividade. 0 mundo corriqueiro da Sra. Jones não estaria, pois, imune à acidentalidade e à contra-intuitividade? Creio que sim. Entendo que a crença verdadeira "Eu (Sra. Jones) possuo um Ford funcionando bem", a partir de "O meu Ford, que estacionei há alguns minutos, encontra-se lá fora", estaria autorizada, obtendo a condição de resolução a partir de (CF) e (CF2) e demais condições de função própria, constituindo, pois, conhecimento. Aponto, enfim, para a crítica de A. Chignell à concepção de Crisp sobre (CFg) segundo probabilidade, destacando contra-exemplos em que tal revisão é incapaz de evitar a acidentalidade. Fundamentalmente, a reconstrução de Crisp ignora que a definição de anulador não-anulado (presente na cláusula definitória (d) de mini-ambiente cognitivo desfavorável) simplesmente (e erroneamente) exclui a priori a possibilidade de existirem "anuladores refutantes de anuladores" ("rebutting defeaters of defeaters"). ${ }^{102}$

${ }^{102}$ Cf. A. CHIGNELL, Accidentally true belief and warrant, op. cit., p. 450-3. E mesmo sob uma cláusula $\left(\mathrm{d}^{*}\right)$, cf. ibidem, p. 453, a reelaborada definição de mini-ambiente cognitivo desfavorável é ineficaz para apreender casos relevantes. 
2. T. M. Botham sequer considera a análise contrafatual de (CF), mas só a análise probabilística de (CF2). O contra-exemplo e o conseqüente argumento contra (CF2), mostrando que esta é lacunar, enquadram-se na idéia que mencionei que (CF) e (CF2) operam de modo independente. Afinal, dado o exemplo das fazendas reais e de fachada, uma interpretação contrafatual conferiria favorabilidade ao mini-ambiente em questão e, com as demais condições, autorização à crença. Por outro lado, creio que o exemplo, ainda que possível, sofre de má formulação de candidatos relevantes a $S$ - contrário ao que se verifica no último exemplo de Plantinga. Os candidatos a $S$ e $S^{*}$ nos exemplos referidos de Botham podem ser trivialmente conjugados. A sua separação é irrelevantemente arbitrária, tornando desnecessária a formulação de $\left(\mathrm{CF}^{*}\right)$ - que considero inócua ao problema da irresolução do ambiente cognitivo. Com isso, o suposto problema de que também (CF2*) falha em mostrar como desfavoráveis (muitos) ambientes cognitivos intuitivamente desfavoráveis, como o da Sra. Jones no exemplo de base, reforça a independência de (CF) e (CF2) - as quais, sendo independentes, não são excludentes. Ocorre que $(\mathrm{CF})$ permite mostrar a desfavorabilidade da crença da Sra. Jones "Eu possuo um Ford funcionando bem" a partir de "O meu Ford, que estacionei há alguns minutos, encontra-se lá fora".

Na verdade, Plantinga pretende com a (CF2) mostrar que $M B E$ e DMBE devem ser suficientemente coincidentes em termos de circunstâncias relevantes à crença, avaliada, epistemicamente, por recurso à probabilidade. É possível, porém, criar cenários em que a (CF2) não serve nem para indicar mini-ambiente cognitivo intuitivamente favorável (cf. o exemplo de A. Chignell) nem para indicar miniambiente cognitivo intuitivamente desfavorável (cf. exemplos de T. M. Botham). Nesses casos, a (CF) deve ser acrescida à (CF2) para compor a favorabilidade. Reconheço que compor a favorabilidade nesses termos (com (CF) ou (CF2)) não é o mesmo que compor a pró-intuitividade ( $\mathrm{com}(\mathrm{CF})$ e (CF2)), tal que a primeira pode se dar sem a segunda, e a segunda implica favorabilidade total. Estritamente destrutivos à favorabilidade do mini-ambiente cognitivo seriam possíveis contraexemplos à sua composição total - por interpretação semântica e por interpretação probabilística -, com as demais condições de autorização por função própria. Obviamente, eles podem existir. Mas, a favorabilidade de mini-ambientes pode sempre existir, ali onde ela se dá de um dos dois modos. É o bastante para crença autorizada e conhecimento? Nos termos de toda a discussão, teria de ser mais bem explanado se a contra-intuitividade, nos termos em questão, tem de estar absolutamente ausente na análise do conhecimento.

3. A. Chignell não argumenta contra a (CF). Sugere dificuldades na determinação, ali, da favorabilidade das circunstâncias atuais de um exercício de crença num dado mini-ambiente - dificuldades com a determinação dos "mundos suficientemente próximos" do contrafatual "Se $p$, então q". Creio que essas dificuldades podem ser desconsideradas. ${ }^{103}$ Ademais, a afirmação de que, no primeiro reparo de

${ }^{103}$ Cf. acima, ao final da seção 2. 
interpretação contrafatual, o MBE e a (CF) são específicos demais - são específicos a uma crença apenas - é inócua. Afinal, uma estratégia de análise de favorabilidade por certa semântica de contrafatuais pode, sem qualquer contradição, e com eficácia, ser relativa a uma crença apenas, em diferentes circunstâncias. A acusação de excessiva especificidade só faz sentido no contexto do segundo reparo de Plantinga à condição de favorabilidade, com o intuito de Chignell de diminuir a validade de $M B E$ e de (CF2). Nesse caso, a segunda condição de favorabilidade de Plantinga, uma vez presente, é dita contra-intuitiva por contínua análise de probabilidade, e esse obstáculo só seria contornável de modo coerente pelo apelo repetido à probabilidade de um conjunto de crenças relevantes, segundo a mesma circunstância.

O serviço prestado pelo estudo de Chignell à precisão da condição de favorabilidade e à eliminação da acidentalidade da crença face à irresolução da condição do ambiente cognitivo se resume a uma ampliação construtiva de (CF2). Porém, simplesmente não vejo como, em (CF2*'), a postulação de um conjunto de crenças que inclui todas as crenças autorizadas que o sujeito poderia formar sobre $O$, com $F$, em $M E$, pode simplesmente excluir contra-exemplos, nos quais o sujeito formaria, em sua maior parte, crenças falsas, mas com alguma autorização, sobre $O$, com $F$, e nos quais uma ou duas crenças verdadeiras e autorizadas, geradas por $F$ sobre $O$, surpreenderiam intuitivamente como conhecimento. Pode $\left(\mathrm{CF}^{*}\right) \mathrm{sim}-$ plesmente excluir crenças verdadeiras obtidas acidentalmente (do ponto de vista do ambiente cognitivo)? Em primeiro lugar, com cada e, pois, com a maioria ou todas as crenças relevantes sobre $O, \operatorname{com} F$, em $M E$, não é o caso que pode ocorrer o mesmo que ocorre com crenças como "Eu possuo um Ford funcionando bem" e "O meu Ford, que estacionei há alguns minutos, encontra-se lá fora", segundo o exemplo padrão? Parece-me que sim, contanto que se apresente um contra-exemplo claramente possível. Continua sendo possível, quanto à produção de crenças básicas verdadeiras, haver acidentalidade generalizada, num mundo em geral enganador, ou, quanto ao mesmo, acidentalidade ocorrente, num mundo às vezes bizarro. Em segundo lugar, que isso não ocorre com cada e, pois, com a maioria ou todas as crenças relevantes sobre $O, \operatorname{com} F$, em $M E$, é algo que, em se relevando o mini-ambiente cognitivo da crença produzida, só poderia ser decidido numa interpretação contrafatual que resultasse em favorabilidade. Em terceiro lugar, as demais crenças verdadeiras relevantes do conjunto de crenças, no exemplo de Chignell sobre o ornitólogo amador, garantem a autorização epistêmica de $B$ - "Aquele pássaro é um pardal canoro" - em termos de favorabilidade por probabilidade, mas a presumida autorização delas mesmas não é analisada, em termos da condição ambiental, por favorabilidade probabilística. Seria analisada, ao que tudo faz crer, por favorabilidade contrafatual. Por último, e mantendo o que foi dito anteriormente sobre favorabilidade e pró-intuitividade na composição total de (CF) e (CF2), o argumento de Chignell parece sugerir, portanto, ainda uma outra composição específica dos dois sentidos primários de favorabilidade de miniambientes cognitivos, nos quais crenças verdadeiras são produzidas. 


\section{Referências}

ALSTON, William. Epistemic warrant as proper function. In: Philosophy and Phenomenological Research. 55:2 (1995), p. 397-402.

BERGMANN, Michael. Externalist justification without reliability. In: SOSA, Ernest and VILLANUEVA, Enrique (eds.). Philosophical Issues14 - Epistemology. Boston/Oxford, Blackwell, 2004, p. 35-60.

BOTHAM, Thad M. Plantinga and favorable mini-environments. In: Synthese. 135 (2003), p. 431-41.

CHIGNELL, Andrew. Accidentally true belief and warrant. In: Synthese. 137 (2003), p. 445-58.

CRISP, Thomas M. Gettier and Plantinga's revised account of warrant. In: Analysis. 60:1 (2000), p. 4250.

FELDMAN, Richard. Plantinga, Gettier, and warrant. In: KVANVIG, Jonathan L. (ed.). Warrant in contemporary epistemology. Essays in honor of Plantinga's theory of knowledge. Lanham, Rowman and Littlefield Publishers, 1996, p. 199-220.

. Proper functionalism. In: Nous. 27:1 (1993), p. 34-50.

GETTIER, Edmund. Is justified true belief knowledge? In: Analysis. 23 (1963), p. 121-3.

GREENE, Richard and BALMERT, N. A. Two notions of warrant and Plantinga's solution to the Gettier problem. In: Analysis. 57:2 (1997), p. 132-9.

KLEIN, Peter. Warrant, proper function, reliabilism, and defeasibility. In: KVANVIG, Jonathan L. (ed.). Warrant in contemporary epistemology. Essays in honor of Plantinga's theory of knowledge. Lanham, Rowman and Littlefield Publishers, 1996, p. 97-130.

MERRICKS, Trenton. More on warrant's entailing truth. In: Philosophy and Phenomenological Research. 57:3 (1997), p. 627-31

. Warrant entails truth. In: Philosophy and Phenomenological Research. 55:4 (1995), p. 841-55.

NOZICK, Robert. The tracking theory. In: LUPER, Steven (ed.). Essential knowledge. Readings in epistemology. New York, Pearson, 2004, p. 135-8.

PLANTINGA, Alvin. Alvin Plantinga replies. In: KVANVIG, Jonathan L. (ed.). Warrant in contemporary epistemology. Essays in honor of Plantinga's theory of knowledge. Lanham, Rowman and Littlefield Publishers, 1996, p. 305-78.

- Précis of Warrant: the current debate and Warrant and proper function. In: Philosophy and Phenomenological Research. 55:2 (1995), p. 393-6.

. Reliabilism, analyses and defeaters. In: Philosophy and Phenomenological Research. 55:2 (1995), p. 427-64.

. Warrant and accidentally true belief. In: Analysis. 57:2 (1997), p. 140-5

. Warrant and designing agents: a reply to James Taylor. In: Philosophical Studies. 64 (1991), p. 203-15.

- Warrant: the current debate. New York/Oxford, Oxford University Press, 1993a

- Warrant and proper function. New York/Oxford, Oxford University Press, 1993b.

- Warranted Christian belief. New York/Oxford, Oxford University Press, 2000.

. Why we need proper function. In: Nous. 27:1 (1993), p. 66-82.

PUST, Joel. Warrant and analysis. In: Analysis. 60:1 (2000), p. 51-7.

RYAN, Sharon. Does warrant entail truth? In: Philosophy and Phenomenological Research. 56:1 (1996), p. 183-92.

SHOPE, Robert K. Gettier problems. In: CRAIG, Edward (ed.). Routledge Encyclopedia of Philosophy. New York/London, Routledge, 1998, Vol. 4, p. 54-9.

SOSA, Ernest. Postcript to "Proper functionalism and virtue epistemology". In: KVANVIG, Jonathan L. (ed.). Warrant in contemporary epistemology. Essays in honor of Plantinga's theory of knowledge. Lanham, Rowman and Littlefield Publishers, 1996, p. 271-80.

STEUP, Matthias. Proper and improper use of cognitive faculties: a counterexample to Plantinga's proper functioning theory. In: Philosophy and Phenomenological Research. 55:1 (1995), p. 409-13.

SWAIN, Marshall. Warrant versus indefeasible justification. In: KVANVIG, Jonathan L. (ed.). Warrant in contemporary epistemology. Essays in honor of Plantinga's theory of knowledge. Lanham, Rowman and Littlefield Publishers, 1996, p. 131-46. 
SWINBURNE, Richard. Response to Warrant. In: Philosophy and Phenomenological Research. 55:2 (1995), p. 415-9.

TAYLOR, James E. Plantinga on epistemic warrant. In: Philosophy and Phenomenological Research. 55:2 (1995), p. 421-6.

. Plantinga's proper functioning analysis of epistemic warrant. In: Philosophical Studies. 64 (1991), p. 185-202 